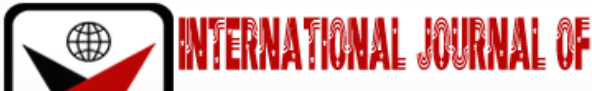

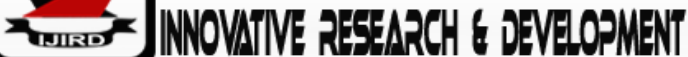

ISSN 2278 - 0211 (Online)

\section{Assessment Practices: Ascertaining Views and Level of Understanding of Kindergarten Teachers in the Kumasi Metropolis, Ghana}

\begin{tabular}{c} 
Dr. Michael Subbey \\
Lecturer, Department of Early Childhood Education, \\
University of Education, Winneba \\
Nurudeen Iddriss Muhammed \\
Lecturer, Department of Education and Professional Studies, \\
Early Grade Unit, Bagabaga College of Education, Tamale \\
\hline
\end{tabular}

\begin{abstract}
:
The thrust of the study was to investigate the various assessment practices teachers employ in assessing children with intellectual disabilities in inclusive classrooms in the Kumasi metropolis as majority of them do not follow many recommended assessment practices. A descriptive survey design was espoused using a sample of 120 early childhood teachers from 22 public inclusive schools in the Kumasi Metro. The purposive sampling technique was used to select all 22 public inclusive schools, while convenience sampling technique was employed to select the actual respondents for the study. Questionnaire was used to gather the research data. Means and Standard deviations were used as statistical tools to analyse the data. The findings revealed that most inclusive public kindergartens teachers in the Kumasi metropolis have a positive view about assessment practices and confirmed to employing it in assessing children with intellectual disabilities in inclusive classrooms. It was also evident that most inclusive public kindergarten teachers in the Kumasi metropolis have knowledge about assessment practices in inclusive schools. In spite of the positive areas recorded about the use of assessment practices, more needed to be done by the teachers to manage the diverse needs of children with intellectual disabilities in inclusive schools. It was therefore recommended that more workshops and in-service training should be organized to inclusive public kindergarten teachers in the Kumasi metropolis with respect to the updated ways of adopting assessment practices for children with intellectual difficult.
\end{abstract}

Keywords: Assessment, practices, views, understanding, kindergarten, teachers

\section{Introduction}

There is enough evidence that in schools, assessment merely refers to tests, examinations and grading (Lissitz \& Schafer, 2000). According to Dean (1999), most teacher education programmes skim over classroom assessment, leaving early childhood teachers to assess in the way they were assessed when they were in school. Campbell and Evans (2000) evaluated pre-service teacher who had completed course work in educational measurement and found that student early childhood teachers did not follow many assessment practices recommended. The National Council of Teachers of Mathematics, NCTM, (2000) held that assessment has the potential to enhance mathematics learning and to promote students' interest in mathematics. This is too general a statement considering the fact that in most school's assessment means testing and grading (van de Wallen, 2001). Gullickson (1984) has the view that most early childhood teachers believe they have adequate knowledge of testing and measurement, more to experience than university course work.

Researchers and organizations have specified the content domain in which early childhood teachers need to develop assessment skills. Among the commonly discussed skills are choosing appropriate methods, developing paper and pencil test, administration and scoring tests interpreting standardized test results, evaluating and improving assessment instruments, using assessment in decision making and grading (Airasia, 1994; Stiggens 1992).

McMillan, Myran and Workman (2002) in their study, aimed at describing the nature of classroom assessment and grading practices, found that early childhood teachers were mostly interested in assessing learner's mastery or achievement and that performance assessment was used frequently. Morgan and Watson (2002) reported that most middle and high schoolteachers use teacher-constructed tests to assess learners' achievement. In addition, Morgan and Watson found that most early childhood teachers view classroom assessment as an added requirement to their teaching job and not as a tool to improve their teaching.

Brookhart (2011) proposed assessment knowledge and skills for teachers by emphasizing that, teachers need to understand learning in the content area they teach, be able to set and apply learning intentions consistent with content and depth of the curriculum goals, and possess the strategies for communicating the expectations of the learning 
intentions to students. Again, teachers need to have the ability to develop scoring schemes to quantify student performance for making informed educational decisions, be skillful in administering external assessments and interpreting their results.

In another study, by Chapman (2011) in New Zealand, on the assessment practices of early childhood teachers in New Zealand outdoor education tertiary programmes, it was found that early childhood teachers were generally highly skilled outdoor education practitioners; however, there were indications that there were gaps of understanding of theoretical assessment concepts. Early childhood teachers seemed to find summative assessment challenging but they routinely used formative assessment to promote learning and worked hard at providing quality opportunities for learning. The use of assessment criteria was common practice. The role of professional judgement in assessment decisions were treated with suspicion because it was seen as too subjective. However, it became clear that professional judgement was essential aspect of their assessment practices.

It is accepted that the proper use of assessment requires teachers to possess deep knowledge about the method or the procedures involved in using it. The American Federation of Teachers (AFT), the National Council on Measurement in Education (NCME), and the National Education Association (NEA) (1990) jointly indicated that, in using assessment, teachers should competently be able to choose and develop methods appropriate for assessment decisions, to administer, score and interpret results, and use the results when making educational decisions about students. The standards show that, teachers using assessment need to develop valid grading procedures, communicate assessment results to various audiences and recognize unethical, illegal, and inappropriate methods and uses of assessment.

Brookhart (2011) proposed assessment knowledge and skills for teachers by emphasizing that, teachers need to understand learning in the content area they teach, be able to set and apply learning intentions consistent with content and depth of the curriculum goals, and possess the strategies for communicating the expectations of the learning intentions to students. To Brookhart (2011), teachers need to also understand the purposes of the assessment type, and be able to apply it, be skillful in analyzing assessment type methods, be skillful in providing meaningful feedback on student work. Again, teachers need to have the ability to develop scoring schemes to quantify student performance for making informed educational decisions, be skillful in administering external assessments and interpreting their results. Furthermore, teachers need to be able to apply educational decisions made out from classroom assessments, be able to communicate assessment information to students to motivate them to learn, and understand the legal and ethical issues in the classroom assessment practices.

Koh (2011) indicated that assessment can be a powerful tool in making improvements in educational systems, and as such, Calderhead (1996) report that its effectiveness depends on teachers' knowledge due to the continual interaction between teachers and students'. Knowledge in assessment by teachers is very vital in education because it gives them the impetus to do what is required for students to achieve what society expects from them. According to Darling-Hammond (2013), teacher involvement in the design, use, and scoring of performance-based assessments has the potential to powerfully link instruction, assessment, student learning, and teacher professional development. In a policy document prepared in the United States, Darling-Hammond (2013) indicated that the use of high-quality standards and performance-based assessments over time has been shown to improve both teaching and learning. As teachers become more experts in their practice through involvement and engagement with performance-based assessments, the outcomes for students can be expected to improve. If used wisely, this approach has the potential to address multiple important education goals through one concentrated investment (Darling-Hammond, 2013).

Many problems have bedeviled effective assessment practices over the world; with Ghana not being an exception. These problems include (but not limited to) teachers' inadequate knowledge regarding the basic assessment concepts (Xu and Brown, 2016; Deluca, Lapointe-Mcewan, 2016 \& Luhanga,2016; Stiggins, 2005) limited teacher training in assessment and failure of teachers to employ and adhere to assessment and measurement guidelines they learned (Murukutla, 2019).

The study seeks to examine the testing practices of teachers in public inclusive kindergartens in Ghana (Kumasi in particular) in terms of their views on development construction, administering and scoring of classroom or teacher-made tests and ascertain their level of knowledge with regards to them. As children with disabilities are still struggling with educational exclusion, and present worrying drop-out rates, as teaching models, assessment procedures, and curricula are not tailored to accommodate their needs (UNESCO, 2009)

\subsection{Objectives of the Study}

- Examine the views of kindergarten teachers regarding assessment practices in use in inclusive early childhood centres in the Kumasi metropolis.

- Ascertain the level of teacher knowledge about assessment practices in inclusive early childhood centres in the Kumasi metropolis.

\subsection{Research Questions}

The study was guided by the following research questions

- What are the views of teachers regarding assessment practices for children with intellectual disabilities in inclusive classrooms in the Kumasi metropolis?

- What is the level of teacher knowledge about assessment practices in inclusive early childhood centres in the Kumasi metropolis? 


\subsection{Significance of the Study}

Since kindergarten teachers in the public schools in Ghana are homogeneous, based on the qualifications, the conclusions and recommendations made could be quite relevant and a guide to all kindergarten teachers in public early childhood centres on how to assess children with intellectual disabilities. Currently, the education system in Ghana practices an examination-oriented learning culture, in which teaching and learning are more likely to be driven by marks and qualifications. This study encourages shifts in practices to better educate students who need to respond well to demands of today's societies. More so, the findings could help shape the views of early childhood teachers with regards to making the right choices in terms of assessment at the early childhood level and the requisite form of knowledge needed to put those views into practice as-- knowledge guide's practice.

\section{Methodology}

The Descriptive survey study was employed in this study. As descriptive method tends to "look at individuals, groups, institutions, methods and materials in order to describe, compare, contrast, classify, analyse and interpret the entities and the events that constitute their various fields of inquiry" (Cohen, Manion, \& Morrison, 2000).

The population for the study included 1,139 teachers from 158 public kindergartens in the Kumasi metropolis.

A sample size of 120 teachers was involved in the study from a total number of 22 public inclusive kindergartens. Out of the 158 public kindergartens in the Kumasi metropolis, only 22 of these schoolsinclude children with intellectual disabilities in their early childhood level, thus from kindergarten to primary three. The researcher then fell on all teachers at the early childhood levels in these schools.

An introduction letter from the Kumasi Metro education office to all heads and circuit supervisors of participating schools was obtained and attached to this letter was the list of these twenty-two (22) public inclusive schools.

The researcher employed the Purposive and Convenience Sampling respectively: firstly, the selection of all the twenty-two (22) public intellectually inclusive schools in the region per the researcher's judgment of how useful they would be for the study; secondly, the selection of teachers from kindergarten one (1) \& two (2) and primary one to three as these are the Early Childhood classes. A case was also made for Early childhood centres that had more than two kindergarten teachers.

A self-designed questionnaire was used for the study. A questionnaire was used for the study because it offered the researcher the opportunity to sample the perceptions of a larger population. Participants were assured of anonymity and so they were more truthful in responding to the questions than they will be for instance, a personal interview, particularly when it involved sensitive or controversial issues. Internal consistency meant that data collected, measured or generated remained the same under expect trials. It was therefore necessary to ensure that research instruments were reliable in case the research method was repeated elsewhere in different samples. Therefore, reliability was ensured through expect judgment and pre-testing.

The information that was gathered from the study using the questionnaires was checked for accuracy, clarity of expression, and completeness. The responses to the questionnaires were organized and analysed with respect to the research questions on which the instruments were design for the study using bar charts frequency tables and means and standard deviations. In essence, the questionnaires were serially numbered, coded and scored. The Statistical Product for Service Solutions (SPSS version 21.0) was used to facilitate data analyzation. Specific questions were formulated to allow for the investigation of the research problem. Tables were constructed to represent the four Likert type scaled response subgroups of "strongly agree", "agree", "disagree", and "strongly disagree" for analysis and discussion.

Access and approval were gained from the Department of Early Childhood and the Ghana Education Service before data was gathered for the purposively selected research sites and participants in the Kumasi Metropolitan Education unit (Bryman, 2016; Cresswell, 2013). The whole process of inquiry was guided by ethics, and therefore did not interfere with the rights of participants (Bryman, 2016).

\section{Results}

\subsection{Explore the Views of Kindergarten Teachers Regarding Assessment Practices in Use In Inclusive Early Childhood Centres in the Kumasi Metropolis}

The researcher ascertained how inclusive public kindergarten teachers in the Kumasi metropolis viewed assessment practices and how they employ it in assessing children with intellectual disabilities in inclusive classrooms. The results for the study are presented in Table 1. 


\begin{tabular}{|c|c|c|c|c|}
\hline Statements & MS & SD & Kurtosis & MR \\
\cline { 2 - 4 } & & \multicolumn{2}{c|}{ Std. Error } & Statistic \\
\cline { 2 - 4 } & \multicolumn{3}{|c|}{ Criterion Score =2.50 } \\
\hline $\begin{array}{c}\text { I have adequate knowledge of testing and measurement } \\
\text { for pupils with intellectual disabilities }\end{array}$ & 3.88 & .724 & .101 & 1 st \\
\hline $\begin{array}{c}\text { I view classroom assessment as an added requirement to } \\
\text { my teaching profession }\end{array}$ & 3.78 & .687 & .588 & 2 rd \\
\hline $\begin{array}{c}\text { I am interested in assessing students' mastery or } \\
\text { achievement and that performance assessment is used } \\
\text { frequently }\end{array}$ & 3.48 & .631 & .688 & $3 \mathrm{rd}$ \\
\hline $\begin{array}{c}\text { I have diverse assessment and grading practices for pupils } \\
\text { with intellectual disabilities in the inclusive classrooms }\end{array}$ & 3.17 & .531 & .620 & 4 th \\
\hline $\begin{array}{c}\text { Assessment is a tool to improve effective teaching and } \\
\text { learning in the inclusive classroom }\end{array}$ & 3.14 & .506 & .189 & 5 th \\
\hline I do not follow many assessment practices recommended & 1.74 & .649 & .147 & $6^{\text {th }}$ \\
\hline
\end{tabular}

Table 1: Descriptive Results on Inclusive Public Kindergartens Teachers'

Views on Assessment Practices for Children with Intellectual Disabilities

Source: Field Data (2020) ( $R S=120)$

Key: $M=$ Mean, $S D=$ Standard Deviation, $M R=$ Means Ranking, $R S=$ Retrieved Sample

Table 1 presents results on public kindergarten teachers and their view about assessment practices and how they employ it in assessing children with intellectual disabilities in inclusive classrooms. Starting with the Kurtosis values, the results show that the variables follow a normal distribution. This is based on the reason that the kurtosis values were within the acceptable limit for normal distribution of \pm 2 (George \& Mallery, 2011). This indicates that the data was normal and as such the descriptive statistics were deemed appropriate for the analysis.

From the descriptive analysis, the results indicate that, generally, most inclusive public kindergarten teachers in the Kumasi metropolis have a positive view about assessment practices and confirm to employ it in assessing children with intellectual disabilities in inclusive classrooms. For example, most of the inclusive public kindergarten teachers in the Kumasi metropolis indicated that they have adequate knowledge of testing and measurement for pupils with intellectual disabilities $(M=3.88>C S$ (2.50), $S D=.724, K=.101, n=120)$ and this explains that most of the teachers have a positive view about assessment practices by having adequate knowledge of testing and measurement for pupils with intellectual disabilities.

In another results, most of the public kindergarten teachers in the Kumasi metropolis pointed out they view classroom assessment as an added requirement to their teaching profession $(M=3.78>C S(2.50), S D=.687, K=.588$, $n=120$ ) and this could elucidate that majority of the public kindergartens teachers in the Kumasi metropolis see classroom assessment as an added requirement to their teaching profession and this could influence how they assess children with intellectual disabilities in inclusive classrooms. The teachers were again of the view that they have diverse assessment and grading practices for pupils with intellectual disabilities in inclusive classrooms $(M=3.17>C S(2.50), S D=.531, K=.620$, $n=120$ ). It was again found that most teachers view assessment as a tool to improve effective teaching and learning in the inclusive classroom and this could have an impact on how they assess children with intellectual disabilities in inclusive classrooms $(M=3.14>C S(2.50), S D=.506, K=.189, n=120)$. Lastly, it was found that few of the Inclusive public kindergarten teachers in the Kumasi metropolis do follow many assessment practices recommended in assessing intellectual disabilities in inclusive classrooms $(M=1.74>C S(2.50), S D=.649, K=.147, n=120)$.

- RQ2: Ascertain the level of teacher knowledge about assessment practices in inclusive early childhood centres in the Kumasi metropolis.

It must be established that any teacher teaching in public kindergarten could have some education in assessment practices in inclusive education. This motivated the researcher to find out the level of teacher knowledge about assessment practices in inclusive early childhood centres in the Kumasi metropolis. The accumulated results are presented in Table 2. 


\begin{tabular}{|c|c|c|c|c|}
\hline \multirow[t]{3}{*}{ Statements } & MS & SD & Kurtosis & \multirow[t]{2}{*}{ MR } \\
\hline & & Std. E & Statistic & \\
\hline & \multicolumn{4}{|c|}{ Criterion Score =2.50 } \\
\hline $\begin{array}{c}\text { I am knowledgeable in the content area I teach, as I am able to } \\
\text { set and apply learning intentions consistent with content and } \\
\text { depth of the curriculum goals. }\end{array}$ & 3.97 & .671 & .698 & 1 st \\
\hline $\begin{array}{c}\text { My involvement in the design, use, and scoring of performance- } \\
\text { based assessments has the potential to powerfully link } \\
\text { instruction, assessment, pupils` learning, and teacher } \\
\text { professional development. }\end{array}$ & 3.86 & .347 & .588 & $2^{\text {nd }}$ \\
\hline $\begin{array}{c}\text { I can use Assessment need to develop valid grading procedures } \\
\text { for pupils with intellectual disabilities in the inclusive } \\
\text { classroom. }\end{array}$ & 3.84 & .687 & .138 & $3^{\text {rd }}$ \\
\hline $\begin{array}{c}\text { I am skillful in analyzing assessment type methods, and skillful } \\
\text { in providing meaningful feedback on pupils' work in the } \\
\text { inclusive classroom }\end{array}$ & 3.81 & .565 & .620 & 4th \\
\hline $\begin{array}{c}\text { I am aware that effective assessment depends on teachers' } \\
\text { knowledge due to the continual interaction between teachers } \\
\text { and pupils }\end{array}$ & 3.77 & .454 & .101 & $5^{\text {th }}$ \\
\hline $\begin{array}{c}\text { I am capable of choosing and developing methods appropriate } \\
\text { for assessment practices suitable for pupils with intellectual } \\
\text { disabilities in the inclusive classroom }\end{array}$ & 3.69 & .714 & .171 & $6^{\text {th }}$ \\
\hline $\begin{array}{l}\text { I understand the purposes of the assessment type, and am able } \\
\text { to apply it }\end{array}$ & 3.67 & .501 & .151 & 7th \\
\hline $\begin{array}{l}\text { I possess the strategies for communicating the expectations of } \\
\text { the learning intentions to pupils with intellectual disabilities }\end{array}$ & 3.59 & .649 & .147 & $8^{\text {th }}$ \\
\hline $\begin{array}{l}\text { I am able to apply educational decisions made out from } \\
\text { classroom assessments for pupils with intellectual disabilities }\end{array}$ & 3.54 & .449 & .147 & $9^{\text {th }}$ \\
\hline $\begin{array}{c}\text { I am capable of administering, scoring and interpreting } \\
\text { assessment results for educational decisions }\end{array}$ & 3.48 & .671 & .688 & $10^{\text {th }}$ \\
\hline $\begin{array}{c}\text { I am able to communicate assessment information to pupils to } \\
\text { motivate them to learn and understand the legal and ethical } \\
\text { issues in the classroom assessment practices }\end{array}$ & 3.44 & .506 & .189 & 11th \\
\hline $\begin{array}{c}\text { I have the ability to develop scoring schemes to quantify pupil's } \\
\text { performance for making informed educational decisions, and } \\
\text { skillful in administering external assessments and interpreting } \\
\text { their results } \\
\end{array}$ & 3.24 & .206 & .123 & $12^{\text {th }}$ \\
\hline & & & & \\
\hline
\end{tabular}

Table 2: Descriptive Results on Level of Teacher Knowledge about Assessment Practices in Inclusive Education Source: Field Data (2020)

(RS=120)

Key: $M=$ Mean, $S D=$ Standard Deviation, MR=Means Ranking $R S=$ Retrieved Sample

Table 2 depicts the results on the level of teacher knowledge about assessment practices in inclusive education. Reporting on the Kurtosis values, the results show that the variables follow a normal distribution. This is based on the reason that the kurtosis values were within the acceptable limit for normal distribution of \pm 2 as suggested by George and Mallery (2011). This indicates that the data was normal and as such the descriptive statistics were deemed suitable for the analysis. Observing the descriptive analysis (Ms and SDs), the results give ample indication to settle that largely, most public kindergartens teachers in the Kumasi metropolis have knowledge about assessment practices in inclusive education. This was evident after most of the items scored a mean greater than then Criterion Score ( $>$ CS).

Dwelling on the individual items, most of the public kindergartens teachers in the Kumasi metropolis indicated that they are knowledgeable in the content area they teach, as they are able to set and apply learning intentions consistent with content and depth of the curriculum goals ( $M=3.97>C S$ (2.50), $S D=.671, K=.698, n=120$ ). The majority further asserted that their involvement in the design, use, and scoring of performance-based assessments has the potential to powerfully link instruction, assessment, pupils` learning, and teacher professional development $(M=3.86>C S(2.50)$, $S D=.347, K=.588, n=120$ ). This explains why most of them have knowledge about assessment practices in inclusive education.

In another evidence, it was found that most of the Inclusive public kindergarten teachers in the Kumasi metropolis can use assessment need to develop valid grading procedures for pupils with intellectual disabilities in the inclusive classroom (M=3.84>CS (2.50), $S D=.687, K=.138, n=120)$. This elucidates why most of them have knowledge about assessment practices in inclusive education. The results further show that majority of the Inclusive public kindergarten teachers in the Kumasi metropolis are skillful in analyzing assessment type methods, and skillful in providing meaningful feedback on pupils` work in the inclusive classroom ( $M=3.81>C S(2.50), S D=.565, K=.620, n=120)$. This explicates why most of them have knowledge about assessment practices in inclusive education. 
The teachers further confirmed that they are aware that effective assessment depends on teachers' knowledge due to the continual interaction between teachers and pupils $(M=3.77>C S(2.50), S D=.454, K=.101, n=120)$. Others were of the view that they are capable of choosing and developing methods appropriate for assessment practices suitable for pupils with intellectual disabilities in the inclusive classroom ( $M=3.69>C S(2.50), S D=.714, K=.171, n=120)$. The majority of the Inclusive public kindergarten teachers in the Kumasi metropolis indicated they understand the purposes of the assessment type and are able to apply it $(M=3.67>C S$ (2.50), $S D=.501, K=.151, n=120)$. Others were of the view that they possess the strategies for communicating the expectations of the learning intentions to pupils with intellectual disabilities ( $M=3.59>C S(2.50), S D=.649, K=.147, n=120)$.

\section{Discussions}

The results lend ample support to the work of Dean (1999), who asserted that most teacher education programs skim over classroom assessment, leaving early childhood teachers to assess in the way they were assessed when they were in school. Campbell and Evans (2000) evaluated pre-service teacher who had completed course work in educational measurement and found that early childhood teachers did not follow many assessment practices recommended. The National Council of Teachers of Mathematics, NCTM, (2000) held that assessment has the potential to enhance mathematics learning and to promote students' interest in mathematics.

Similarly, McMillan, Myran, and Workman (2002) in their study, aimed at describing the nature of classroom assessment and grading practices, found that early childhood teachers were most interested in assessing students' mastery or achievement and that performance assessment was used frequently. Morgan and Watson (2002) reported that most middle and high school teachers use teacher-constructed tests to assess students' achievement. In addition, Morgan and Watson found that most early childhood teachers view classroom assessment as an added requirement to their teaching job and not as a tool to improve their teaching.

Cooney (1992) reported a strong link between assessment and grading in the minds of high school early childhood teachers. That the latter is the product of the former. A study conducted by Gurski (2008) in Canada, examined secondary classroom early childhood teachers' assessment and grading practices in one urban school division. It compared the assessment practices of ten elementary early childhood teachers over a period of 11 weeks with Ohio's fourth and sixth-grade science Proficiency Tests. Evidence from the survey demonstrated that early childhood teachers in inclusive schools have diverse assessment and grading practices and that they have begun to explore the potential for assessment to assist all students in their learning

In another study, by Chapman (2011) in New Zealand, on the assessment practices of early childhood teachers in New Zealand outdoor education tertiary programs, it was found that early childhood teachers were generally highly skilled outdoor education practitioners; however, there were indications that there were gaps of understanding of theoretical assessment concepts. Early childhood teachers seemed to find summative assessment challenging but they routinely used formative assessment to promote learning and worked hard at providing quality opportunities for learning. From the discussions above, the problem with early childhood teachers in inclusive classrooms has neither been the availability of a clear roadmap as to how to assess children with intellectual disability nor the lack of knowledge to effectively assess these children, but the will to put into action what has been learned in their colleges and universities. Though some tend to be selective with what they are capable enough of using, this however does not augur well for effective teaching and learning as a good assessment must be wholistic in nature and should not only take one form.

Again, many early childhood teachers in inclusive classrooms will trade product for process. Though the reverse will seek to serve the child well. Teachers are only interested in the performance of these young ones not paying much attention to the little progress chalked every day. The situation worsens when the results from these assessments are used for grading. Wherever there is grading, there is competition: wherever there is competition there is no serene atmosphere to bring out the best from the child with intellectual disability.

\section{Level of Teacher Knowledge about Assessment Practices in Inclusive Education}

The results support the ideas of Brookhart (2011) who proposed assessment knowledge and skills for teachers by emphasizing that, teachers need to understand learning in the content area they teach, be able to set and apply learning intentions consistent with content and depth of the curriculum goals, and possess the strategies for communicating the expectations of the learning intentions to students. Similarly, Brookhart (2011), pointed out that teachers need to also understand the purposes of the assessment type, and be able to apply it, be skillful in analyzing assessment type methods, be skillful in providing meaningful feedback on student work. Again, teachers need to have the ability to develop scoring schemes to quantify student performance for making informed educational decisions, be skillful in administering external assessments and interpreting their results. Furthermore, teachers need to be able to apply educational decisions made out from classroom assessments, be able to communicate assessment information to students to motivate them to learn, and understand the legal and ethical issues in the classroom assessment practices.

Recognizing the need for teachers to possess adequate knowledge in educational assessment, Plake and Impara (1992) developed an instrument titled the “Teacher Assessment Literacy Questionnaire (TALQ)" consisting of 35 items to measure teachers' assessment literacy. The TALQ was based on the Standards for Teacher Competence in Educational Assessment of Students (AFT, NCME, \& NEA, 1990). In his discussion of the assessment knowledge, Popham (2006) asserted the need for a continuous in-service assessment training aligned with the assessment realities. In a survey of assessment knowledge of purposively sampled 69 teacher candidates in Bangladesh by adapting Teacher Assessment Knowledge Questionnaire, Volante and Fazio (2007) found that the self-described levels of assessment knowledge remained relatively low for the candidates across the four years of the teacher education program. 
From the foregone discussions, for a teacher to have adequate knowledge about assessment practices in inclusive classroom, he/she must possess some qualities and capabilities, as spelt out by Brookhart (2011). Among these qualities; teachers need to understand learning in the content area they teach, be able to set and apply learning intentions consistent with content and depth of the curriculum goals, and possess the strategies for communicating the expectations of the learning intentions to students. Evidence from the table shows that teachers in Inclusive public kindergartens in the Kumasi Metropolis possessed these qualities.

The capabilities on the other hand include; understanding the purposes of the assessment type, and being able to apply it, being skillful in analyzing assessment type methods, being skillful in providing meaningful feedback on student work. Besides, teachers need to have the ability to develop scoring schemes to quantify student performance for making informed educational decisions, be skillful in administering external assessments and interpreting their results. Furthermore, teachers need to be able to apply educational decisions made out from classroom assessments, be able to communicate assessment information to students to motivate them to learn, and understand the legal and ethical issues in the classroom assessment practices. Evidences from the table show that teachers from the inclusive public kindergartens in the Kumasi metropolis possess these capabilities as many of them were able in applying educational decisions made out from classroom assessments for pupils with intellectual disabilities. Also, capable of administering, scoring and interpreting assessment results for educational decisions and able to communicate assessment information to pupils to motivate them to learn and understand the legal and ethical issues in the classroom assessment practices. Lastly, teacher's ability to develop scoring schemes to quantify pupil's performance for making informed educational decisions, and skillful in administering external assessments.

\section{Key Findings}

From objective one, results gave evidence that generally, most public kindergartens teachers in the Kumasi metropolis have a positive view about assessment practices and confirm to employ it in assessing children with intellectual disabilities in inclusive classrooms. Assessing the objective two, it was evident that most public kindergartens teachers in the Kumasi metropolis have knowledge about assessment practices in inclusive education.

\section{Conclusions}

It was evident from the findings of the study that Inclusive public kindergarten teachers in the Kumasi metropolis were well equipped with assessment practices. Teachers having such a sensitive responsibility of assessing and making decisions concerning children's academic progress are expected to be professional in the process of achieving testing strategies.

\section{Recommendations}

- More workshops and in-service training should be organized to inclusive public kindergarten teachers in the Kumasi metropolis with respect to how to follow recommended assessment practices, choose and develop methods appropriate for assessment practices suitable for pupils with intellectual disabilities in the inclusive classrooms. This could be achieved through the collaboration of the ministry of education, the institute of education and other stakeholders of education.

- The teacher education division should also make it a point to equip the teachers with skills with regard to their ability to develop scoring schemes to quantify pupils` performance for making informed educational decisions. This is because assessment practices form an integral part of the teaching profession since it is the most widely used as a channel for assessing students in Ghana.

- Teachers should also be sensitized on regular basis on the importance of their assessment practices with regard to construction, administration, and scoring of tests by the Teacher Education (T. Ed) and the Special Education (SpEd) divisions. Teachers should know about the implication of their assessment practices and its effect on validity and reliability which will adversely affect how decisions are made on their students. This could be achieved through effective supervision from the office of the education directorate.

\section{References}

i. Alkharusi, H., Aldhafri, S., Alnabhani, H., \& Alkalbani, M. (2012). Educational Assessment Attitudes, Competence, Knowledge and Practices. An Explorative Study of Muscat Teachers in the Sultanate of Oman. Journal of Education and Learning, 1(2), 217-232.

ii. Ary, D., Jacobs, L. C., \& Razavieh, A. (2002). Introduction to research in education.

iii. Beckman, C. E., Senk, S. L., \& Thompson, D. R. (1997). Assessment and grading in high school mathematics classrooms. Journal for research in Mathematics Education, 187-275

iv. Birenbaum, M., \& Feldman, R. A. (1998). Relationships between patterns and attitudes towards two assessment formats. Educational research, 40(1), 90-98.

v. Black, P. H., \& Lee, C. C., Marshall, B., and William, D. (2004). Working inside the box: Assessment for learning in the classroom. Phi Delta Kappan, 86(1), 8-21.

vi. Bryman, A., \& Becker, S. (2012). Qualitative research. Oxford, UK. Oxford University

vii. Bryman, A. (2016). Social Research Methods. New York: Oxford University Press, Inc

viii. Calderhead, J. (1996). Teachers Beliefs and Knowledge. London: Routledge Falmer

ix. Campbell, C., \& Evans, J. A. (2000). Investigation of preservice teachers' classroom assessment practices during student teaching. The Journal of Education Research, 93(6), 350-355. 
x. Campbell, C., Murphy, J. A., \& Holt, J. K. (2002) Psychometric analysis of an assessment literacy instrument: Applicability to preservice teachers. In annual meeting of the Mid-Western Educational Research Association, Columbus, $\mathrm{OH}$.

xi. Carrie, C., Lasset, C., Alpetite, C., Maire, J. P., Haile-Meder, C., Hoffstetter, S., ... \& Seng, S. H. (1994). Multivariate analysis of prognostic factors in adult patients with medullablastoma. Retrospective study of 156 patients. Cancer, 74(8), 2352-2360.

xii. Chapman, R. (2011). 'Choices of methodology for cooperative education researchers', Asia-Pacific Journal of Cooperative Education, Retrieved Nov. 02, 2019 from: http://www.apjce.org/volum_1_1_pp_1_8.pdf

xiii. Cheek, J. (2008). Researching collaboratively: Implications for qualitative research and researchers. Qualitative Health Research, 18(11), 1599-1603.

xiv. Cimer, S. O., Cakir, I., \& Cimer, A. (2010). Teachers views on the effectiveness of in-service courses on the new curriculum in Turkey. European Journal of Teacher Education, 33(1), 31-34.

xv. Cohen, L., Manion, L., \& Morrison, K. (2007). Research methods in education $\left(6^{\text {th }}\right.$ ed) London: Taylor and Francis

xvi. Cohen, L., Manion, L., \& Morrison, K. (2013). Research methods in education ( $7^{\text {th }}$ ed) London: Routledge Falmer

xvii. Cook, B.G. \& Traverse M. (2000). Inclusive teachers' attitudinal ratings of their students with disabilities. The Journal of Special Education, 40(4), 230-238.

xviii. Cooney, T. J. (1992). Teacher education as an exercise in adaptation. Professional development for teachers of mathematics, 9-22.

xix. Darling-Hammond, L. (2010). Teacher education and the American future. Journal of teacher education, 61(1-2), 35-47.

xx. Darling-Hammond, L. (2013). Getting teacher evaluation right. What really matters for effectiveness and improvement. Teacher College Press.

xxi. Darling-Hammond, L., \& Adamson, F. (2013). Developing assessment of deeper learning. The cists and benefits of using tests that help students learn. Stanford Center for Opportunity Policy in Education.

xxii. Dean, J. (1999). Managing the primary. London: Routledge

xxiii. DeLuca, C., \& Klinger, D. A. (2010). Assessment literacy development: identifying gaps in teacher candidates' learning. Assessment in Education: Principles, Policy and Practice, 17(4), 419-438.

xxiv. Deluca C., Lapointe D. Mcewan, \& Luhanga U. (2016) "Teacher assessment literacy: A

$x x v$. review of international standards and measures", Educational Assessment,

xxvi. Evaluation and Accountability, 28(3), pp. 251-272.

xxvii. Denzin, N. K. \& Lincoln. Y. S. (2011). Introduction: The discipline and practice of qualitative research. In: N. K. Denzin and Y. S. Lincoln, ed. The sage handbook of qualitative research. 4th ed. pp.1-19. Thousand Oaks, CA: Sage.

xxviii. Gay, L., \& Diehl, P. (1992). Research methods for business and management: MacMillan Coll Div.

xxix. Goslin, D. A. (1967). Teachers and testing. New York: Russell Sage Foundation

xxx. Gullickson, A. R. (1984). Teacher perspectives of their instructional use of tests. The Journal of Educational Research, 77(4), 244-248.

xxxi. Gurski, L. F. (2008). Secondary teachers' assessment and grading practices in inclusive classrooms. (Doctoral dissertation, University of Saskatchewan).

xxxii. Lincoln, Y. S., \& Denzin, N. K. (Eds). (2003). Turning points in qualitative research: Tying knots in a handkerchief. Rowman Altamira.

xxxiii. McMillan, J. H., Myran, S., \& Workman, D. (2002). Elementary teachers' classroom assessment and grading practices. The Journal of Educational Research, 95(4), 203-213.

xxxiv. Mertler, C. A. (2003). Preservice Versus in service Teachers' Assessment Literacy: Does Classroom Experience Make a Difference?

xxxv. Mertler, C. A., \& Campbell, C. (2005). Measuring Teachers' Knowledge and Application of Classroom Assessment Concepts: Development of the "Assessment Literacy Inventory". Online Submission.

xxxvi. Morgan, C., \& Workman, A.(2002). The interpretive nature of teachers' assessment of students' mathematics: Issues for equity. Journal for research in Mathematics education, 78-110.

xxxvii. Murukutla, M.( 2019)“The Effects of Background, Classroom Assessment Competence, Self-efficacy, and Selfperceived Assessment Skills on Classroom Assessment Practices of Teachers in India". Doctoral dissertation, University of Nevada, Las Vegas

xxxviii. Nable, M. J., Raheem, K., Agbemaka, J. B., \& Sabtiwu, R. (2016). Multiple solutions approach (MSA): Conception and practices of primary school teachers in Ghana. International Journal of Research in Education and Science, 2(2), 333-344.

xxxix. Nitko, A. J. (2004). Educational assessment of students. Englewood Cliffs, NJ: Prentice Hall

xl. O'leary, Z. (2004). The Essential guide to doing research. Sage.

xli. Odom, S. L., Horner, R. H., Snell, M. E. \& Blacher, J.,(Eds.). (2007) Handbook of Developmental Disabilities. New York: The Guilford Press

xlii. Phillips, V., \& Bubbles, L. (2000). Consultation-based programming: Instituting the collaborative ethic in schools. Exceptional children, 56, 219-304

xliii. Plake, B. S., Impara, J. C., \& Fagger, J. J. (1992). Assessment competencies of teachers: A national survey. Educational Measurement: Issues and Practice, 12(4), 10-12. 
xliv. Popham, W. J. (2006). All about accountability/phony assessments: Buyer beware. Educational Leadership, 64(3), 86-87.

xlv. Reddy, L. A (2018). Teacher coaching supported by formative assessment for improving classroom practices. School Psychology Quarterly, 33(2), 293

xlvi. Schafer, W. D., \& Lissitz, R. W. (1987). Measurement training for school personnel recommendation and reality. Journal of Teacher Education, 38(3), 57-63.

xlvii. Senk, S. L., Beckman, C. E., \& Thompson, D. R. (1997). Assessment and grading in high school mathematics classrooms. Journal for research in Mathematics Education, 187-275.

xlviii. Stiggins. R. J. (2005).Assessment crisis: The absence of assessment for learning. Phi Delta Kappa. 8 (10), 758765.

xlix. Xu Y. \& G. T. Brown (2016) “Teacher assessment literacy in practice: A reconceptualization", Teaching and Teacher Education, 58, pp. 149-162 